\title{
Mothers at Work: The Fiscal Implications of the Proposed Ontario Childcare Rebate
}

by

\author{
Jacob Kim and Alexandre Laurin
}

- The newly elected government in Ontario pledged in its electoral platform to implement a childcare rebate program, which would reimburse up to 75 percent of the childcare expenses of low-income families, with the childcare subsidy rate gradually declining as family income grows. In this E-Brief, we examine the fiscal implications of the proposed rebate.

- At first, the fiscal cost of the proposed rebate would be, at most, $\$ 945$ million per year. Then, we expect the proposed rebate to induce some mothers of young children - whose decisions to take on paid work are sensitive to childcare costs - to enter the workforce. Over the long run, as many as 112,787 additionally employed mothers would generate extra fiscal revenues for the Ontario government, reducing the net fiscal cost by about 38 percent, to $\$ 588$ million annually.

- Furthermore, the employment gain would create a large fiscal windfall for the federal government - perhaps as much as $\$ 1.1$ billion per year over the long run - exceeding by far the net provincial cost of the program. Unless the federal government is prepared to use this fiscal dividend to increase its transfers to Ontario in support of childcare, the federal government appears better fiscally positioned to implement such a childcare rebate scheme.

Ever-increasing daycare costs strain the wallets of many Ontario families, and can discourage parental employment. To confront these challenges, the provincial Progressive Conservative Party pledged in its electoral platform to implement a childcare rebate program. The new program, modelled after Quebec's refundable tax credit on childcare expenses, would reimburse up to 75 percent of the childcare expenses of low-income families. The electoral platform put the cost of the childcare rebate at $\$ 389$ million per year. ${ }^{1}$

The authors wish to thank Rosalie Wyonch, Daniel Schwanen, William Molson, Thomas Wilson, members of the Fiscal \& Tax Competitiveness Council and anonymous reviewers for input and helpful comments on an earlier draft. Responsibility for the simulation results, views expressed, and any remaining errors is ours.

1 "Ontario PCs announce child-care rebate for low-income families," Globe and Mail, April 28, 2018. 
Society might have multiple reasons to subsidize childcare. One view is that childcare is an expense incurred for earning income, and as such, people should not be taxed on their income spent on childcare. Another view is that its price should be lowered, through a subsidy, because the social benefit of more childcare exceeds its private cost. A more pragmatic motivation is that the costs should be lowered for working mothers with young children, in particular, whose decisions about taking paid work are sensitive to childcare costs. This would induce more such mothers to enter the workforce, which would generate extra fiscal revenues for government, thus lowering the net cost of subsidization while promoting economic gender equity.

Currently, the Child Care Expense Deduction (CCED) - a tax deduction applied to the taxable income of the lower-income parent that reduces both federal and provincial taxes - is the only tax provision providing childcare cost relief to Ontario families. CCED claims, however, are limited by income and expense thresholds, leaving out many modest-income families (Laurin and Milligan 2017). In addition, the extent of cost relief provided by the CCED is limited by the schedule of marginal tax rates: lower rates provide less relief. Replacing the CCED with the newly elected PC government's proposed Ontario Childcare Rebate, therefore, would be very beneficial to modest-income families. Combined with the tax benefits provided by the CCED at the federal level, the new rebate would provide generous childcare cost subsidization for most families in Ontario.

In this E-Brief, we examine the fiscal implications of the proposed childcare rebate program. ${ }^{2}$ We begin by estimating the static fiscal cost of the program(i.e., assuming no change in employment) under the scenario in which the new rebate program simply replaces the provincial tax deduction for childcare expenses. We then consider the effect of the program on the employment of mothers, and on the resulting fiscal cost.

We find that the static fiscal cost of the rebate program would be, at most, $\$ 945$ million per year, but we expect the employment response of mothers to reduce this cost over time. In the short term, as many as 59,650 mothers who are currently not working could be induced to join the labour force, decreasing the provincial cost by $\$ 74$ million. Over the long run, the fiscal cost of the rebate program could be $\$ 588$ million per year, or $\$ 358$ million lower than the static cost.

The cost estimates, however, are likely at the high end of possible outcomes, for two reasons. First, very recent increases in provincial support for licensed childcare and the associated full or partial fee subsidies ${ }^{3}$ likely were not entirely picked up by our supporting survey data on childcare expense deductions, so that our estimated fiscal cost might be based on inflated private childcare expenses. Second, we modelled the effect of the extra employment of mothers on personal income and consumption taxes and fiscal benefits, but - unlike that of Fortin, Godbout, and St-Cerny (2013) - our model does not allow for the inclusion of potentially higher corporate profits and capital taxes or potentially higher property taxes. Allowing for these additional impacts on government revenues would naturally further reduce the fiscal cost estimate.

We also find that a much larger share of the revenue windfall from the induced extra employment of mothers would accrue to the federal government, since income tax rates and fiscal benefit reduction rates are much higher federally than they are provincially. We estimate that the federal government could gain as much as $\$ 731$

2 With our focus on fiscal considerations, we do not consider in this E-Brief the possible effects of childcare subsidization on children's health and behaviour (see, for example, Baker, Gruber, and Milligan 2008) or considerations related to the quality control of childcare.

3 Operating expenses with respect to the Child Care and Early Years Programs that support licensed child care and associated full or partial fee subsidies increased by about $\$ 300$ million between fiscal years 2016/17 and 2017/18 alone. 
million per year in tax revenues over the long term from the extra employment, and pay as much as $\$ 410$ million less annually in income-tested benefits, gaining $\$ 1.14$ billion in total and far exceeding the fiscal cost reductions gained by Ontario.

\section{The Ontario Childcare Rebate}

The proposed Ontario Childcare Rebate program would work similarly to Quebec's refundable tax credit. Families earning less than about $\$ 35,000$ could be reimbursed for up to 75 percent of incurred childcare expenses, with the rate declining as family income grows until it reaches 26 percent for families earning over about $\$ 150,000$; the complete rate schedule was not disclosed in the PCs' electoral platform and is still unavailable. The maximum allowable amount per child would be $\$ 6,750$ for children under age six and $\$ 3,750$ for children between seven and fifteen. The proposed program is less generous than Quebec's, where the expense limit is $\$ 9,000$ for children under six and $\$ 5,000$ for children between seven and fifteen. In our modelling of the proposed Ontario rebate program, we used Quebec's refundable sliding credit rate schedule, shown for 2017 in Appendix Table A1.

\section{Our Methodology}

The methodology we use for our simulation closely follows that adopted in a previous C.D. Howe Institute report that modelled a new childcare rebate implemented at the federal level (Laurin and Milligan 2017). We assume that the CCED is replaced by the new rebate program at the provincial level but remains unchanged at the federal level. Our aim is to assess both the static fiscal cost of the proposed program and the dynamic effect through the induced labour supply of mothers, which allows us to estimate how much of the fiscal cost would be recovered through employment gains.

To simulate the effect of the new rebate program, we used Statistics Canada's SPSD/M, a large, sophisticated and widely used tax simulation database of Canadian taxfilers. ${ }^{4}$ This database enables us to compute not only the change in taxes households would pay, but also the change in income-tested benefit payments (such as child benefits) that would result from eliminating childcare deductions or inducing extra work income. We begin by estimating the static fiscal cost, which is the change in the provincial fiscal balance that would result from the implementation of the program, assuming no change in employment. The static cost would be lower than the total amount of childcare rebates paid out because of the CCED's elimination at the provincial level.

To model the effect on mothers' employment, we focus on the extensive margin, where the decision is whether to work or not, and where evidence suggests that most of the shifting in response to childcare price changes occurs (Andresen and Havnes 2018; Laurin and Milligan 2017). We estimate the percentage reduction in the net cost of average childcare for the average mother in Ontario, to which we apply an elasticity rate of $0.24 .{ }^{5}$ Elasticity measures the percentage change in the probability of working for a given percentage change

4 The assumptions and calculations underlying the simulation results were prepared by the authors, and responsibility for the use and interpretation of these data is entirely ours. Note that our simulations for 2019 adjust the childcare sliding credit rate schedule for inflation.

5 The 0.24 estimate is from Baker, Gruber, and Milligan (2008), who study the Quebec system. This estimate is on the lower end of the range found in the literature. 
in the cost of childcare. So, for example, a 10 percent change in the cost of childcare (due to a change in the subsidy rate) would yield a 2.4 percent change in the probability of working.

Looking at the short run, we focus on a sample of mothers of children between the ages of zero and six. For the long run, we extend the analysis to those with children between seven and fifteen. Because work patterns for mothers with young children tend to persist as children reach school age, childcare subsidies have an effect beyond the preschool years (Lefebvre, Merrigan, and Verstraete 2009). This is an important consideration, because the childcare costs of school-age children are low, while any boost to the labour supply would provide consistent tax revenue.

\section{Our Results}

Before considering the potential effects of the proposed childcare rebate on mothers' employment, we estimated that the total amount of rebate paid out would be $\$ 1.27$ billion per year. Ontario would gain $\$ 323$ million from the elimination of the CCED provincially, resulting in a static net annual fiscal cost of $\$ 945$ million (Table 1, row 3).

\section{The Short-term Labour Supply Effects}

We estimated that the tax credit would reduce net childcare costs by 47 percent for a mother who joins the labour force and earns the average employment income of current working mothers of children ages zero to six and pays the average childcare expenses incurred by the average working mother. Using the participation elasticity of 0.24 , we found that the probability of participation increased by 11.2 percent (Appendix Table A2). In the short term, 59,648 stay-at-home mothers would enter the workforce, generating $\$ 2.86$ billion in new employment income (Table 1, column 1). These mothers now would pay $\$ 610$ million in childcare expenses, increasing Ontario rebate payouts by $\$ 337$ million. The Ontario government would recoup $\$ 259$ million in income and consumption taxes and $\$ 152$ million in income-tested benefits. In the short term, the net provincial fiscal cost of the rebate program would be $\$ 871$ million per year after accounting for induced employment gains (a 7.9 percent reduction). The employment-induced fiscal cost reduction for the province would be lower than was estimated federally in Laurin and Milligan (2017), because the province would collect less income tax (lower tax rates) and recoup much less in income-tested benefits than would the federal government. So, a much larger share of the fiscal gains would accrue to the federal government, which would take no part in the rebate program. In the short term, the employment gains would generate $\$ 355$ million more in annual federal tax revenue, and the federal government would pay out $\$ 225$ million per year less in income-tested benefits, for a total fiscal gain of $\$ 580$ million (Table 1 , column 1). On a federal-provincial consolidated government basis, the annual fiscal cost would be reduced to $\$ 291$ million.

\section{The Long-term Labour Supply Effects}

Looking at the long term, we assumed that, in each income group, mothers with children ages seven to fifteen would increase their labour supply by the same proportion as those with younger children, which would likely be the case since, as noted, mothers' work patterns set during their children's younger years persist once the children reach school age. We estimated that, over the long term, 112,787 additional employed mothers would generate $\$ 5.4$ billion in additional employment income (Table 1, column 2). These mothers would spend $\$ 737$ million in childcare expenses, increasing the Ontario rebate payouts by $\$ 404$ million per year. The additional employment income would bring in \$503 million annually in extra provincial tax revenue, and result in \$259 
Table 1: Net Provincial and Federal Fiscal Changes under an Ontario Childcare Rebate Program, 2019

\begin{tabular}{|c|c|c|}
\hline Change (\$millions except Mothers entering workforce) & Short Term & LongTerm \\
\hline Static amount of childcare rebate paid out & 1,268 & 1,268 \\
\hline Elimination of provincial CCED & -323 & -323 \\
\hline Static fiscal cost & 945 & 945 \\
\hline Mothers entering workforce & 59,648 & 112,787 \\
\hline New employment income & 2,859 & 5,400 \\
\hline New childcare expenses to support employment & 610 & 737 \\
\hline New benefits paid out & 337 & 404 \\
\hline Change in provincial taxes & 259 & 503 \\
\hline Change in provincial income-tested benefits & -152 & -259 \\
\hline New net provincial fiscal cost & 871 & 588 \\
\hline Change in federal taxes & 355 & 731 \\
\hline Change in federal income-tested benefits & -225 & -410 \\
\hline New net federal fiscal cost & -580 & $-1,141$ \\
\hline Consolidated federal-provincial net fiscal cost & 291 & -553 \\
\hline
\end{tabular}

million less in income-tested benefits. In total, the program would cost the Ontario government $\$ 588$ million a year - a more substantial 38 percent reduction over the static cost.

Interestingly, Laurin and Milligan (2017) find that such a rebate program, if instituted at the federal level, could yield a greater employment-induced cost reduction - a net fiscal cost close to zero over the long term for the federal government alone, or a 93 percent reduction over the static fiscal cost. This should make instituting this rebate program more fiscally attractive when viewed from the perspective of the federal government than that of the Ontario government.

Unsurprisingly, the federal government would gain the most from the Ontario rebate program. The employment gains would bring in $\$ 731$ million in additional federal tax revenues, and income-tested benefits would fall by $\$ 410$ million per year; combined, Ottawa would gain $\$ 1.14$ billion per year in the long term. On a federal-provincial consolidated government basis, the childcare rebate program could generate a sizable surplus of $\$ 553$ million per year (Table 1).

\section{Conclusion}

The proposed Ontario Childcare Rebate program has important fiscal implications for both the federal and Ontario governments. We estimate that a refundable tax credit for childcare expenses could cost the Ontario 
government up to $\$ 871$ million per year in the short term, and about $\$ 588$ million per year in the long term, after accounting for the increased participation in the workforce of mothers with young children that the subsidy is expected to induce.

But the share of the employment-induced fiscal dividend is greater federally than provincially. The federal government would enjoy a very large windfall - perhaps as much as $\$ 1.14$ billion per year over the long run - exceeding by far the net provincial cost of the program in the long term. Unless the federal government is prepared to use this fiscal dividend to increase its transfers to Ontario in support of childcare, the federal government appears better positioned to implement the rebate program via the tax system. 


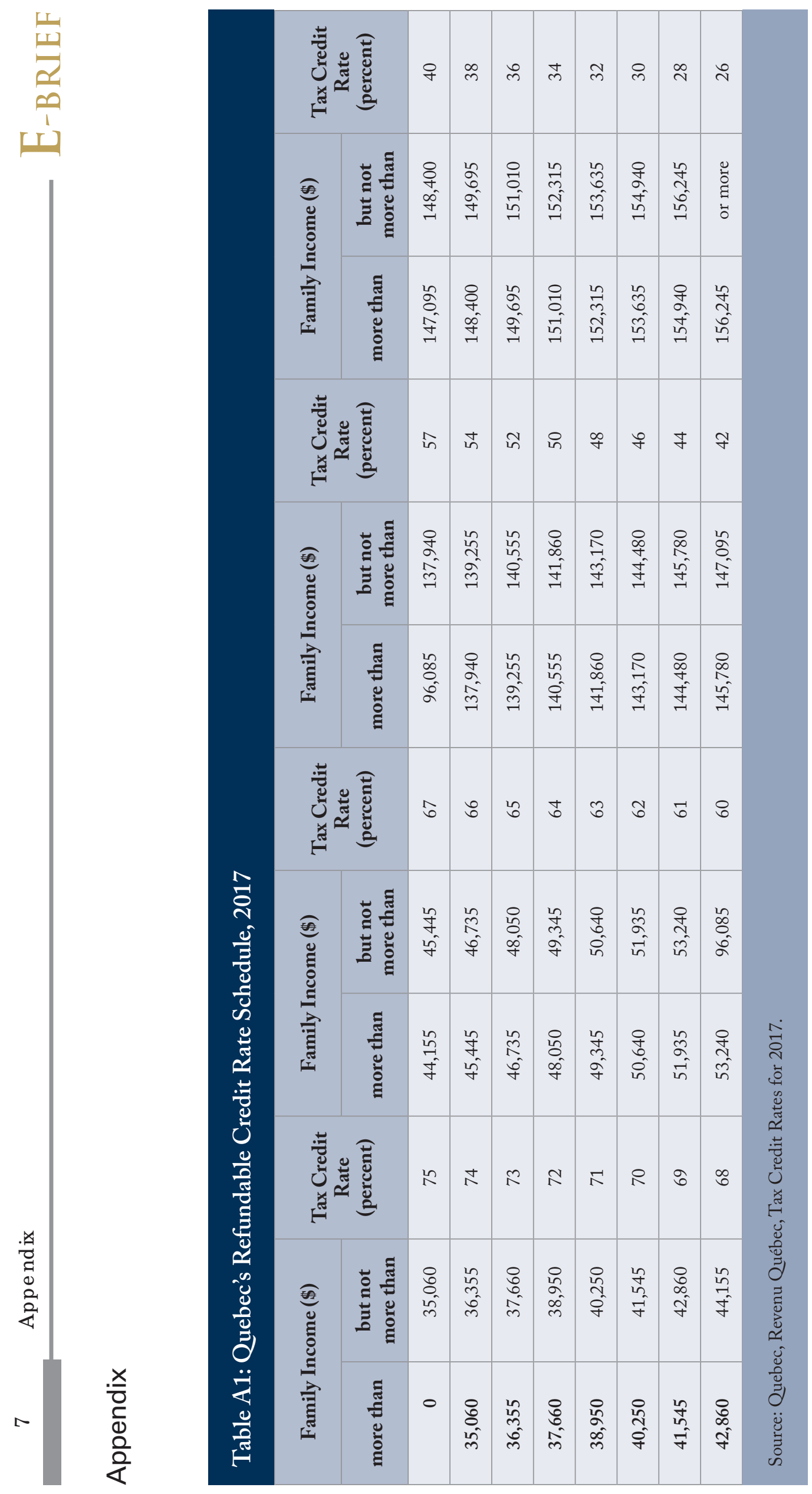




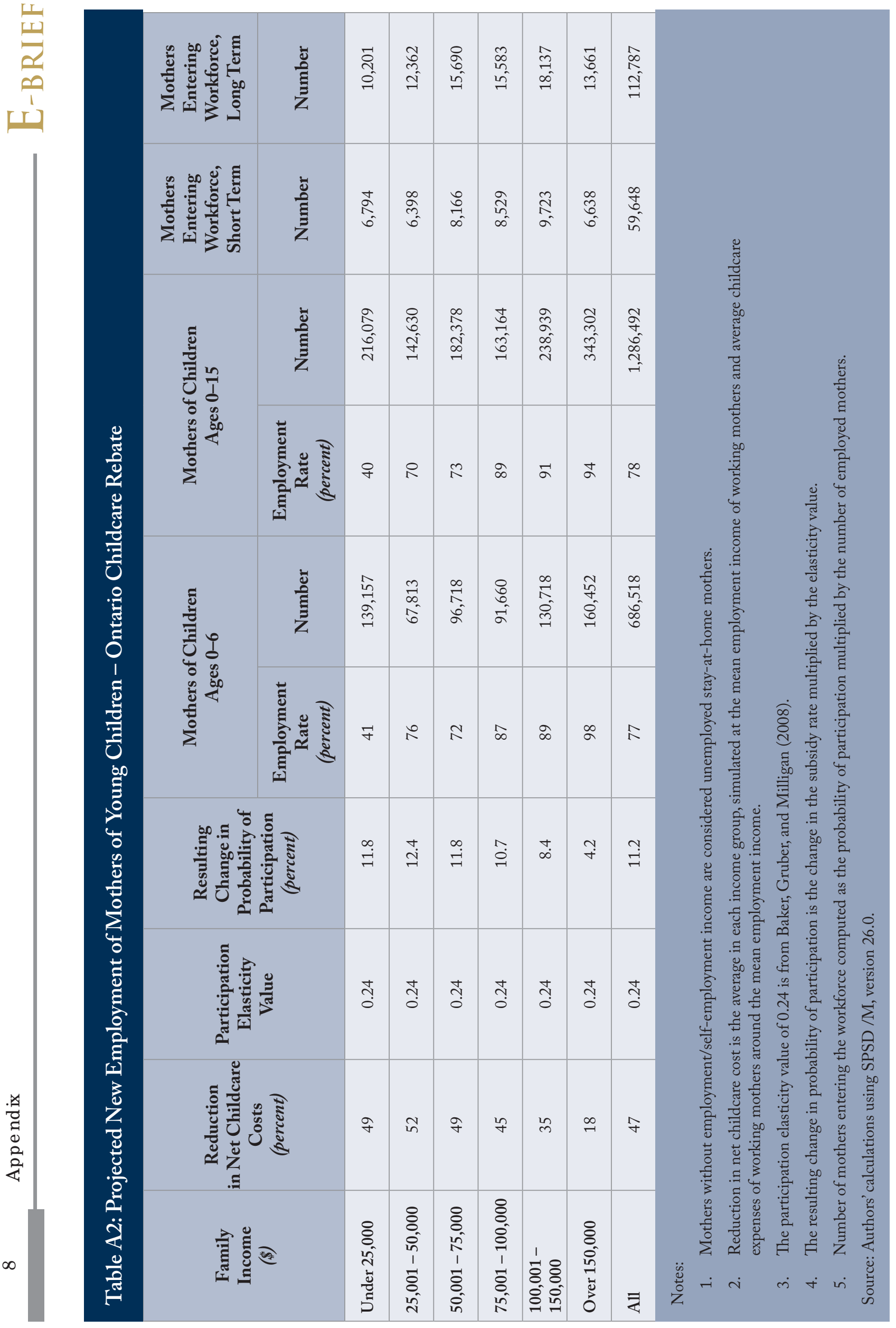




\section{References}

Andresen, Martin Eckhoff, and Tarjei Havnes. 2018. "Child Care, Parental Labor Supply and Tax Revenue.” Discussion Papers 881. Oslo: Statistics Norway. August.

Baker, Michael, Jonathan Gruber, and Kevin Milligan. 2008. "Universal Childcare, Maternal Labor Supply, and Family Wellbeing." Journal of Political Economy 116 (4): 709-45.

Fortin, Pierre, Luc Godbout, and Suzie St-Cerny. 2013. "L'impact des services de garde à contribution réduite du Québec sur le taux d'activité féminin, le revenu intérieur et les budgets gouvernementaux.” Revue Interventions économiques 47.

Laurin, Alexandre, and Kevin Milligan. 2017. Tax Options for Childcare that Encourage Work, Flexibility, Choice, Fairness and Quality. Commentary 481. Toronto: C.D. Howe Institute. May.

Lefebvre, Pierre, Philip Merrigan, and Matthieu Verstraete. 2009. "Dynamic Labour Supply Effects of Childcare Subsidies: Evidence from a Canadian Natural Experiment on Low-Fee Universal Child Care." Labour Economics 16 (5): 490-502.

This E-Brief is a publication of the C.D. Howe Institute. Jacob Kim is a former researcher at the C.D. Howe Institute. Alexandre Laurin is Director of Research, C.D. Howe Institute.

This E-Brief is available at www.cdhowe.org.

Permission is granted to reprint this text if the content is not altered and proper attribution is provided. The views expressed here are those of the authors. The C.D. Howe Institute does not take corporate positions on policy matters. 